\title{
A LOOK AT THE LIFE AND SCIENTIFIC (PEDAGOGICAL) ACTIVITY OF UZBEK GERMAN SCIENTIST, PROFESSOR SHUKHRATKHON IMYAMINOVA
}

\author{
Ramzidin Abdusattorov \\ Candidate Of Philological Sciences, Associate Professor, National University Of Uzbekistan Named After Mirzo Ulugbek, \\ Uzbekistan
}

Sadirjon Yakubov

Candidate Of Philological Sciences, Associate Professor, National University Of Uzbekistan Named After Mirzo Ulugbek, Uzbekistan

\section{ABSTRACT}

One of the leading linguists, translators and German scholars who has played a significant role in Uzbek and German linguistics is the candidate of philological sciences, professor Imyaminova Shukhratkhon Salijanovna. Sh.S. Imyaminova was born in Maslakhat village of Altynkul district of Andijan region in an educated family. He began his pedagogical career in 1975-1977 as a teacher of German at the secondary school No. 60 in the village of Maslahat, Altynkul district, Andijan region. In 1977-1978 he worked as a teacher at the Department of German for junior courses of the Faculty of Foreign Languages of the Andijan State Pedagogical Institute of Languages. Sh.S.Imyaminova worked tirelessly as a young specialist and had a strong love for pedagogy (their family is a dynasty of teachers). Due to his diligence, diligence, dedication and love for his profession, the department in 1978-1980 sent a young specialist to study at the Tashkent State Institute of Foreign Languages (now UzSWLU) at the Faculty of German Philology for a two-year Higher Pedagogical Course.

KEYWORDS: - Philology and language teaching, pairs of words in German and Uzbek, problems of literary translation, phonetics and phonologv.

\section{INTRODUCTION}

Under the leadership of the young specialist, Ph.D., Professor ME Umarkhodjaev, he began serious work in the field of lexicology and phraseology of linguistics. His in-depth research in linguistics on lexicology and phraseology led to the publication of a number of scientific and methodological articles and manuals in this field. During the two-year course, Sh. S. Imyaminova listened to lectures by German scholars working in Uzbekistan on such subjects as "German lexicology", "Analytical and frontal reading", "Text analysis", "German literature". After successful completion of the course, in 19801986 he continued his work at the Department of German Phonetics and Grammar of the Faculty of Foreign Languages of Andijan State Pedagogical Institute of Languages. In his lecture on German Lexicology (2000), he identified important issues such as modern German lexicology, word formation, word classification, and ways to enrich lexicology. An example of this is the student G. A. Tilovova published a textbook "Double words in German and Uzbek" (2008), collected more than 500 pairs of words in German and compared the grammatical, morphological, lexical-semantic in both languages. developed options. Today, this 
CURRENT RESEARCH JOURNAL OF PHILOLOGICAL SCIENCES 2(10): 86-

91, October 2021

DOI: https://doi.org/10.37547/philological-crjps-02-10-17

ISSN 2767-3758

(C)2021 Master Journals

Crossref do

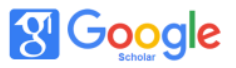

Accepted26 $6^{\text {th } O c t o b e r, ~} 2021$ \& Published $31^{\text {th }}$ October, 2021

textbook is widely used by translators. He also presented a number of dictionaries for Uzbek and German lexicography. Q. Z. Mahmudova, M. M. "German-Uzbek-Russian biological dictionary" (2010) with Hasanova, students Sh. A. Kamalova with "German-Uzbek dictionary of proverbs and sayings" (2013), G. A. With Tilovova created 2 "Uzbek-German-Russian-Latin dictionary of words on forestry" (2019) and the first in our country "German-Uzbek electronic dictionary of forestry" (2021) mobile application. With ZI Sanakulov published "German-Uzbek derivative dictionary of quality lexemes" (2020).

In the textbook "German phraseology" (2011) Sh.S.Imyaminova collected a large number of phraseologies in German and Uzbek, as well as classified the similarities and differences between the two languages. It is safe to say that Sh.S.Imyaminova's contribution to the development of Uzbek and German lexicology and phraseology is invaluable.

In 1986-1991, when he began working as a teacher at the Department of German Philology, Faculty of Romance and Germanic Philology, Tashkent State University (now the National University of Uzbekistan), he also conducted research on the theory and practice of translation. Relying on the advice of a wellknown translator and German scholar, Professor H. Rakhimov, Sh. S. Imyaminova has published many textbooks, manuals, translated works, scientific articles, poems, stories in the field of translation studies. He began translating stories, hilarious adventures and detective stories from German into Uzbek as a student. His first translation was published in Andijan in 1979 in the 105th issue of the newspaper "Communist Labor" under the title "Cheerful Hands". After that, the magazine "Gulkhan" and "Culture of Uzbekistan", "Andijan Haqiqati", "Pakhtaabad", "Teachers", "Tashkent Evening", "Literature and Art of Uzbekistan", "Altynkul", "Asian Bazaar",
"Trust", " Marifat ”,“ Huquq ”,“ Sado ”,“ Darakchi ", "Meridian ", " Turkiston ", " Hurriyat ", " Efendi "," National University of Uzbekistan "and published more than 500 lines of literary translations. Sh.S.Imyaminova made a significant contribution to the science of translation studies in the translation of works from German into Uzbek, from Uzbek into German. The textbook "Theory and Practice of Translation", published in 2005, is still an important guide in improving the knowledge and skills of students. Sh. S. Imyaminova's series of literary translations include "The Mysterious World of Fairy Tales" (2006), "The Mysterious Witness" (2007), "Samples from German Poetry" (2012), "Samples from German Prose" (2012), "When Does the Mind Come In?" (2013), "Austria" (2014), Martin Auer's "Strange Stories About the Wise Balaban and His Daughter Selda" (2019) from German to Uzbek, some of Alisher Navoi's Wisdoms, Uzbek Folk Tales $(2013,2020)$ He skillfully translated his work from Uzbek into German. He has published manuals such as "Collection of Translations of Literary Texts" (2013), "Translation of Works of Art" (2018) for students to gain theoretical and practical knowledge. He has extensive scientific and practical experience in translation. S. At the initiative of Imyaminova, the club "Young translator" and "Young linguist" were established at the Department of German Philology. Today, he leads the Young Translator Circle to teach literary translation, where he teaches young translators the secrets of translating from German to Uzbek and from Uzbek to German. To date, his students have published more than 30 books in the practice of literary translation. Participates in the discussion of works translated from German into Uzbek and from Uzbek into German at the Writers' Union of Uzbekistan. Also, Sh. S. Imyaminova is one of the scholars who has made a worthy contribution to the growth of the number of translated works in 
CURRENT RESEARCH JOURNAL OF PHILOLOGICAL SCIENCES 2(10): 86-

91, October 2021

DOI: https://doi.org/10.37547/philological-crjps-02-10-17

ISSN 2767-3758

(C)2021 Master Journals

Crossref do

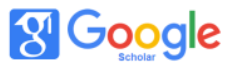

Accepted $26^{\text {th }}$ October, 2021 \& Published $31^{\text {th }}$ October, 2021

German and Uzbek in our country.

From 1991 to 2008 she worked as the head of the laboratory of technical means of the Faculty of Foreign Philology of the National University of Uzbekistan and senior lecturer of the Department of German Philology. From 1991 to 2004 she worked as the Deputy Dean for Spiritual and Educational Affairs of the Faculty of Foreign Philology. Due to his passion for science, in 1995 he became a Ph.D., Professor N.A. Under Avazbaev's scientific guidance, he began to study the phonetics and phonology of the German and Uzbek languages in a comparative style. He worked on a dissertation on "Linguistic and statistical study of syllable formation (based on multi-syllable words)." Meanwhile, Ph.D., Professor NA Avazbaev passed away prematurely. Nevertheless, Sh.S.Imyaminova wrote and published the "Textbook of practical phonetics of the German language" (2004) for 1 st year Uzbek groups. In the manual, along with the rules of German language, vowels and consonants, pronunciation, intonation, the department conducted lectures and practical classes for students on the subject of practical and theoretical phonetics of the German language.

Noticing the leadership skills of Sh.S.Imyaminova, the university administration allowed her to work as the dean of the Faculty of Foreign Philology in 2008-2012. The Faculty of Foreign Philology flourished, especially when Sh.S.Imyaminova was the dean. As a result of his simultaneous educational, scientific, spiritual and educational work at the faculty, the faculty has achieved many successes and developed. From 2008 to 2012, the faculty prepared 12 candidates of sciences and 1 doctor of sciences. Through his efforts, the Germanistisches Zentrum (2008) was opened at the Department of German Philology on the basis of a grant, international projects in collaboration with the Institute of German
Studies and the DAAD of the University of Westphalia, Münster, Germany (2008). He made a huge contribution to the provision of the center with books of great value and value.

Sh.S.Imyaminova translated her dissertation from Russian into Uzbek with the advice and assistance of Ph.D., Professor Abdi Eshankulovich Mamatov. As a researcher at the Institute of Language and Literature named after Alisher Navoi of the Academy of Sciences of Uzbekistan, he continued to work on the dissertation. The dissertation was discussed at scientific seminars of various universities and in 2009 successfully defended his dissertation at the Institute of Language and Literature of the Academy of Sciences of the Republic of Uzbekistan on "Linguistic and statistical study of syllable formation (based on multi-syllable words)." In his monograph "Hinge formation in German and Uzbek" (2010) he first described the theory of syllables, syllable formation in German and Uzbek, word length and depth in two languages, consonant coefficients, the relationship between open and closed syllables. The problems and issues raised in this monograph serve to the development of comparative linguistics, as well as to reveal the current problems of phonetics and phonology.

In 2011 Sh.S.Imyaminova was awarded the title of associate professor. From 2009 to 2016 he was a direct initiator of the creation of "GermanUzbek" and "Uzbek-German" dictionaries on the basis of an agreement with the Institute of German Studies of the University of Westphalia, Germany. He studied at the Goethe Institutes in Munich, Berlin, Dresden, Freiburg and Munster, Germany in 1996, 2002, 2008, 2011. Currently, the National University of Uzbekistan in cooperation with the Goethe Institute in Tashkent, Germany is cooperating in the implementation of new modern textbooks in German in the educational process. 
CURRENT RESEARCH JOURNAL OF PHILOLOGICAL SCIENCES 2(10): 86-

91, October 2021

DOI: https://doi.org/10.37547/philological-crjps-02-10-17

ISSN 2767-3758

(C)2021 Master Journals

sonem

8 Google

Accepted $26^{\text {th }}$ October, 2021 \& Published $31^{\text {th }}$ October, 2021

Radjaapova Sabohat, Khojimatov Doniyor, Alimova Hamro, Hasanova Farangiz took the leading places in the competition "Oratory" organized by the German Embassy in Tashkent every spring. His students Mohigul Bahodirova and Olima Nematova became the winners of the Alisher Navoi State Scholarship. One of them, Mohigul Bahodirova, is currently a 2nd year doctoral student at Grayswald University (PhD) in Germany. In 2020, Dilola Odilkhanova and Jamshid Davronov took second place in the Republican Olympiad in German language and literature.

Sh.S.Imyaminova attached great importance to improving the teaching of German in schools of the republic. Because at a time when the teaching of German as a subject in schools has been declining sharply in recent years, the German language textbooks were first revised and published in accordance with modern requirements, eliminating errors, omissions and deficiencies in old textbooks. He himself put forward the idea of creating quality textbooks and textbooks based on four competencies. At his initiative, first-year students of lyceums and colleges based on reading, writing, listening and speaking skills "Zum Ziel" for Uzbek and Russian schools (2014), third-year students of lyceums and colleges "Deutsch zum Ziel" for Uzbek schools (2016) , L.T. Published in co-authorship with Germanists such as Kholiyorov, S.Ya.Abdullaeva, Sh.S.Kholmatov, S.A.Ziyaeva, D.T.Ismatullaeva, MSMajidova. Today, these textbooks are taught in all schools and lyceums of the country.

Sh.S.Imyaminova is a scholar in the field of comparative literature, Uzbek and German literature. He published textbooks in German for students of the Faculty of Uzbek Philology, such as "Representatives of German classical literature" (2004), "Representatives of German literature of the XX century" (2004),
"Representatives of Uzbek literature" (2004) with his student, a well-known young translator $\mathrm{H}$. Kochkarova did. This is the result of the scholar's tireless and significant work in Uzbek and German literature.

Sh. S. Imyaminova has established a huge partnership with Germany since 2018, when she became the head of the Department of German Philology. Under his leadership, in 2019, professors and teachers of the department participated in seminars of the German publishing house "Klett" (Klett) and "Huber" (Huber) and received more than 40 free textbooks and manuals. In 2019, Dr. Helge Kleifeld from Germany was able to come to the faculty to give lectures and seminars to the students of the Department of German Philology. This cooperation was beneficial for the development and future of the department. As a result of cooperation $\mathrm{H}$. Clayfeld is preparing a textbook for students of local lore, which is about to be published in Germany. The scientist further expanded his cooperation with Germany. A meeting was held with the university administration to sign a memorandum with representatives of the 2020 Konrad Adenauer Foundation.

Today Sh.S.Imyaminova heads the department of German philology and at the same time in the direction of 5120100 - Philology and language teaching (German) undergraduate education "German lexicology", "Translation theory and practice", "Introduction to German philology", "Comparative typology" Lectures and seminars on "Local Studies of Uzbekistan" and "Direct and indirect translation issues", "Reading and writing practice", "Formation of intercultural communication in foreign language teaching", specialty 5A120102-Linguistics (German) lectures to master's students on "Modern Linguistics", "Comparative Linguistics" and a special course "Current Problems of Phraseology 
CURRENT RESEARCH JOURNAL OF PHILOLOGICAL SCIENCES 2(10): 86-

91, October 2021

DOI: https://doi.org/10.37547/philological-crjps-02-10-17

ISSN 2767-3758

(C)2021 Master Journals

Crossref do

8 Google

Accepted $26^{\text {th }}$ October, 2021 \& Published $31^{\text {th }}$ October, 2021

and Phraseography", conducts seminars. At the same time, he supervises graduate dissertations, master's dissertations and doctoral dissertations in the specialty 10.00 .06 - Comparative Literature, Comparative Linguistics, Translation Studies (Philology). Under his leadership, 20 master's and 56 bachelor's theses have been successfully defended in the last 8 years.

Sh.S. Imyaminova Tashkent State Institute of Oriental Studies, Uzbek State University of World Languages DSc.27.04.2017. DSc.26.04.2018, a member of the Scientific Seminar under the Scientific Council No. 21.01 and awarding degrees at the National University of Uzbekistan, Samarkand State Institute of Foreign Languages, Andijan State University. Fil.01.10 is the Scientific Secretary of the Scientific Seminar under the Scientific Council.

Sh.S.Imyaminova is a member of the Women's Association of Women Scientists of Uzbekistan. Since 2012, he has been a member of the examination commission for admission to the basic doctoral program in German at the National University of Uzbekistan and the University of World Languages of Uzbekistan, and since 2018, chairman of the National University of Uzbekistan and Tashkent State Technical University.

The above information testifies to the wide scientific and pedagogical range of Sh.S.Imyaminova. As proof of this, Sh. S. Information about Imyaminova is included in the book "Women Scholars of the Capital", published in 2016, dedicated to the 25th anniversary of independence of the Republic of Uzbekistan. In 2020, the Higher Attestation Commission of the Republic of Uzbekistan on the recommendation of the Council of the National University of Uzbekistan and for his invaluable theoretical and practical contribution to comparative linguistics and literature and translation studies, Professor of Translation Studies.

F.f.n., Professor Sh. S. Imyaminova has published more than 200 scientific articles, 2 monographs, 9 textbooks, 11 textbooks, 4 biobibliographic indexes, 5 manuals, 5 dictionaries, 5 translations, 1 patent, 2 electronic dictionaries. was announced. The works created by the multifaceted scholar during his meaningful and exemplary life have become a rich heritage of Uzbek and German linguistics and literature, and have taken a worthy place in the linguistic treasury.

\section{REFERENCES}

1. Имяминова Ш. С. Немис ва ўзбек тилларида бўғин хосил бўлиши. Монография. Тошкент, "Мумтоз сўз" нашриёти, 2010. 5.5 б.т.

2. Имяминова Ш. С. Слоговая организация слова в современном немецком и узбекском языках (на материале многосложных слов). Монография. Тошкент, “Замин нашр” нашриёти, 2019 йил, 14 б.т.

3. Имяминова Ш. С., Абдуллаева С. Я. Мажидова M. C. Deutsch. Zum Ziel (ўзбек мактаблари учун) Дасрлик. Lehrbuch für das 1. Studienjahr der Colleges und akademischen Lyzeen. Toschkent, "Ўзбекистон", 2016. 13.95 б.т.

4. Имяминова Ш. С., Холиёров Л. Т., Абдуллаева С. Я. Deutsch - 10 Klasse (ўзбек мактаблари учун). Дарслик. Ўрта мактабларнинг 10-синфи учун дарслик. Тошкент, “Давр” нашриёти, 2017. 28 б.т.

5. Имяминова Ш. С., Холиёров Л. Т., Абдуллаева С. Я. Deutsch - 10 Klasse (рус мактаблари учун). Дарслик. Ўрта мактабларнинг 10-синфи учун дарслик. Тошкент, “Давр” нашриёти, 2017. 28 б.т. 
CURRENT RESEARCH JOURNAL OF PHILOLOGICAL SCIENCES 2(10): 86-

91, October 2021

DOI: https://doi.org/10.37547/philological-crjps-02-10-17

ISSN 2767-3758

(C)2021 Master Journals

Crossref doi) 81 Google

Accepted $26^{\text {th }}$ October, 2021 \& Published $31^{\text {th }}$ October, 2021

6. Имяминова Ш. С., Киямова 3., Киямова М. Deutsch - 5 Klasse (рус мактаблари учун). Дарслик. Умумий ўрта мактаблар учун дарслик. Қайта ишланган 4 нашри. Тошкент, “Ўқитувчи” нашриёт матбаа ижодий уйи, 2017. 11.70 б.т.

7. Имяминова Ш. С., Қосимова М. Х., Шокирова Н. Ю. Санъатшунослар учун немис тилидан ўқув қўлланма. Ўқув қўлланма. Тошкент, 2006 (немис тилида). 4,75 б.т.

8. Имяминова Ш. С., Тиловова Г. А. Немис ва ўзбек тилларида жуфт сўзлар. Ўқув қўлланма.Тошкент, "Университет”, 2008. 3.25 б.т.

9. Имяминова Ш. С. Немис тили фразеологияси. Ўқув қўлланма. Тошкент, "Мумтоз сўз" нашриёти, 2011.4,5 б.т.

10. Имяминова Ш. С., Абдуллаева С. Я., Холматов Ш. С., Исматуллаева Д. Т. “Zum Ziel" (лицей ва коллежларнинг 1-курс талабалари ўқитувчилари учун ўқув қўлланма). Ўқув қўлланма. Тошкент, “Давр" нашриёти, 2014. 20 б.т.

11. Имяминова Ш. С., Абдуллаева С. Я., Мажидова M. C. Deutsch. Zum Ziel. Ўқув қўлланма. Lehrerhandbuch für das 1. Studienjahr der Colleges und akademischen Lyzeen. Toschkent, „Ўзбекистон”, 2017. 11 б.т.

12. . Алишер Навоий хикматлари, Ўзбек халқ эртаклари. Таржима. Тошкент, “Мумтоз сўз", $2013 . \quad$ 5,5 б.т.

13. Имяминова Ш. С., Холиёров Л. Т., Абдуллаева С. Я. Австрия. Таржима. Тошкент, “Чўлпон” нашриёти, 2014. 12,75 б.т.

14. Имяминова Ш. С. Бадиий асарлар таржимаси. Услубий қўлланма. Тошкент,
“Камалак”, 2018. 8,3 б.т.

15. Мартин Ауэр. Донишманд Балабан ва унинг қизи Селда хақида ғаройиб воқеалар. Таржима. Тошкент, “Замин нашр" нашриёти, 2019. 